\title{
Strategic Culture of the Western Balkans States
}

\author{
Granit Zela \\ Lecturer, Foreign Language Center, Armed Forces Academy, \\ Training and Doctrine Command, Tirana, Albania \\ E-mail: zelagranit401@gmail.com
}

\section{Doi:10.5901/mjss.2013.v4n10p636}

\begin{abstract}
For the purposes of the paper, the Strategic Culture is defined as "that set of shared beliefs, assumptions, and modes of behavior derived from common experiences and accepted narratives that shape collective identity and relationships to other groups and which determine appropriate ends and means for achieving security objectives". The present study focuses on the Strategic Culture of the Western Balkans States through the study of their security documents and consists of three major parts. The first part analyses Regional Security Cooperation as it is stated in the National Security Strategies of Western Balkans countries. The second part compares the perception of the Relations with International Security Organizations and Approaches to the International Order. Finally, the third part, analyses Interests and Values reflected in these official strategic documents as a fundamental input to the perceptions that shape the Strategic Culture of these countries.
\end{abstract}

Keywords: Western Balkan States, Strategic Culture, National Security Strategies

\section{Brief Overview of the Paper's Analysis}

Over the past half decade, the Western Balkan countries have elaborated and developed an impressive number of security strategy documents. Albania's National Security Strategy was adopted in November 2004 by Parliament. In Bosnia and Herzegovina, a Security Policy was approved in February 2006. In Croatia, Parliament adopted a National Security Strategy in March 2002. Macedonia's National Security and Defence Concept was adopted by Parliament in February 2003. Government of Montenegro adopted a Strategy of National Security in June 2006. In 2007, two drafts of NSS had already been prepared separately in summer 2006 in Serbia, one by advisers to the Prime Minister and the other by advisers to the President Tadic. Security Strategy of Kosovo was adopted in 2010.

Western Balkans is a dynamic unfinished transatlantic security agenda and while Croatia became the 28th EU country on 1 July 2013, we still define in this study, Croatia along with Albania, Bosnia and Herzegovina, Serbia, Macedonia, Kosovo and Montenegro as "Western Balkans". The analysis will reveal attitudes within the country towards Western Balkan neighbors, as reflected by their national security policies. In examining the above issues, the paper will also consider the key national approaches of these countries with regard to regional security cooperation.

\section{Strategic Culture of Interests and Values}

Generally, the documents define national interests and values in a very wide sense, not limiting them to the security context. They include the following: the protection of sovereignty, territorial integrity, the development or protection of the rule of law, democratic institutions, human rights and freedoms, prosperity and economic development. Below the level of abstract and declarative national interest there are a number of issues that are elaborated on in most of the documents upon which there are generally commonly held views. The first among them is the question of regional stability as a national interest. On this issue the main message all documents convey is that the countries of the region are committed to contribute actively to preserving and enhancing peace and stability in their neighbourhood and in South Eastern Europe. This is reflected in various pronouncements contained in the relevant security documents of the respective countries, such as "to be a factor of stability"(Albania), "to be seen as a recognised contributor to peace and stability in South-Eastern Europe" (Macedonia) or to make an "active contribution to the preservation of peace and the development of a favourable security environment" (Serbia). (Gyarmati I. and Stančić D.2007:24)

The issue of national identity occupies an important place among the values that are dealt with in the security documents, as illustrated by wordings such as the "development of national identity" (Albania and Croatia), the "free 
expression of national belonging and the maintenance and upgrading of national and ethnic identity" (Macedonia), and "preserving multiethnic society" (Montenegro) "a peaceful, prosperous and multiethnic state" (Kosovo). Furthermore, the Albanian and Croatian documents provide for the "preservation of national identity and well-being" of their nationals living in other countries. With the exception of Albania, all other countries in the region refer in their strategic documents to the importance of protecting the environment in terms of national security, thus showing a modern and comprehensive approach to security.

Naturally, there are a number of issues on which common views are not held, reflecting an expression of specific national approaches. Two documents refer to the issue of the change of borders, with Albania rejecting "border change by use of force", while the Serbian document cites OSCE documents referring to "maintaining the current state borders". The Macedonian security document takes up specific issues such as internal integration, equal representation of national communities, local self-government and the building of a multiethnic society based on tolerance.

When comparing two Croatian documents - the National Security Strategy of 2002 and the Strategic Defence Review of 2005 - there seems to be markedly different wording related to the use of force by the army: the first document is very explicit in stating that "Croatia is determined to use all available resources, including the armed forces, if necessary, to protect her vital national interests", while such statements are completely lacking in the latter document. In the Serbian Strategic Defence Review particular emphasis is placed - at the level of interests and values - on the principle that foreign troops may only be deployed on national territory if they are mandated by the UN for peacekeeping purposes. The Montenegrin document includes another element as a priority national interest, namely that the country is willing to contribute "to stability and peace beyond Montenegro's borders by... allowing the possibility to use Montenegro's territory, air and sea to support relevant missions undertaken by the UN, EU, OSCE or NATO".

The NSS emphasizes that the vital interests of Albania that are linked to security are: exercise of sovereignty, protection of independence and territorial integrity, protection of constitutional order, protection of life and property, democratic development and economic prosperity. (Gyarmati I. and Stančić D.2007:25)

Kosovo Security Strategy (KSS) states in its preface that "The people of Kosovo is determined to live in a peaceful, prosperous and multi-ethnic state, ensure the well-being of citizens and guarantee the freedoms provided by the Constitution. 'Since the declaration of independence on 17 February 2008, the Government of the Republic of Kosovo has the responsibility to provide security for all citizens. The government is determined to serve its citizens based on democratic values, respect for human rights and support the rule of law. Given the conflicts of the past, the person of Kosovo is committed to develop a multi-ethnic society based on mutual trust and reconciliation." The Strategy considers state security as "the primary responsibility of any democratic country. This includes not only the security and safety of citizens, but also deals with economic and social development of the country. Preserving the rule of law, protection of individual freedoms and individual support of human rights are essential elements for maintaining the security of the state".

In the Section of "Strategic Goals" KSS (2010) refers to the protection of citizens as the responsibility of the Government, need for ministries and agencies to integrate the newly established Government and to involve them in the process of interagency cooperation. "Poverty, unemployment and low education levels pose challenges for social cohesion. The high rate of unemployment in Kosovo and the large number of people living in poverty, development of favorable conditions for employment and investment directly conditioned by effectively combating corruption and organized crime, and to ensure the rule of law, constitute the "strategic goals" and pose a major challenge for the state.

\section{Strategic Culture of Regional Security Cooperation}

The security strategy documents of Western Balkan countries devote varying levels of attention to the issue of regional security cooperation. In Albania, the so-called "Albanian national issue" is a high priority on the list of security strategy objectives, and the relevant Albanian document suggests that "the Albanian national issue will be achieved through European and Euro-Atlantic integration of the countries of the region". Other than this, Albania's national security strategy papers do not deal with regional security cooperation.

Bosnia does not elaborate specifically on regional cooperation in its strategic documents. Only one paragraph and minor references shed some light on its regional cooperation approach. In the section of the document dealing with defence policy, it is stated that the country is "committed to promote its role and importance in regional cooperation", especially regarding implementation of the Agreement on Regional Arms Control. In another section dealing with the principles of defence policy, one finds reference to the "balance of forces and capabilities in... South East Europe". 
By contrast, Croatia's national security strategy devotes appropriate attention to and explains the goals of security policy at regional level. The regional level is first mentioned among its national security principles in the context of security threats originating from that level. In the sub-chapter dealing with neighborly and regional relations, Croatia's relevant strategic document then states that regional cooperation "is an important component of Croatian foreign policy". Here, once again, emphasis is placed on Croatia's self-perceived "multiregional identity".

After enumerating the ongoing regional initiatives, the document expresses interest in "deepening all forms of cooperation" in the region. With regard to international peacekeeping missions, it should be noted that Croatia's readiness to "participate in common military units" is referred to exclusively with regard to the "Northern tier" of its selfproclaimed multiregional identity, namely the Central European states, thus apparently excluding the potential for a joint Balkan effort.

The Macedonian National Security and Defence Concept is rather vague on regional cooperation (on other issues as well). It refers to this issue in a declarative manner, expressing interest in "deepening and finding new forms of cooperation". One section is more specific, and stresses the need to "care for the protection and the permanent improvement of the freedoms and rights of the Macedonian minority living in the neighboring countries".

The Montenegrin Strategy of National Security gives the impression that this country is more directly a part of the world than of its immediate neighborhood. In this short document, the regional level is mentioned twice in the context of possible threats generated by transition processes. Other than this, it makes no attempt whatsoever to elaborate on regional cooperation. (Gyarmati I. and Stančić D.2007:37) The Serbian Strategic Defence Review devotes two paragraphs to the issue, stating that the "country takes (an) active part in regional initiatives and programmes". The document also expresses the view that "joint crisis management and the establishment of regional mechanisms for the risks and threat prevention are significant prerequisites for security consolidation".

In Serbian NSS, regional security cooperation in President's draft NSS prioritises regional stability as one of the three goals of its national security policy. Seeing Serbia as a key factor for regional stability, the President's draft prioritises further enhancement of security stabilisation in the region and democratisation processes, as well as the creation of a climate of mutual trust and confidence. Greater involvement in regional cooperation is emphasized in the third priority of this draft document, in particular the necessity for Serbian armed forces to 'shift from being an importer of security to become an exporter of security' (p.6). The President's draft recognises the possibility of improving its foreign policy position through the use of Serbian forces in peace missions abroad and participation in regional security fora.

The Prime Minister's draft lists regional security cooperation as one of its foreign policy priorities. This section does not include further explanation/motivation for participation in regional security initiatives, but through an examination of the detailed list of areas of possible cooperation, we can conclude that it primarily involves burden-sharing. However, this draft clearly lists the priorities for bilateral cooperation and coordination dealing primarily with the resolution of lingering conflict-related problems such as the status of refugees and borders.

Kosovo Security Strategy (2010) ensures that the Government is committed to contribute to the functioning of regional and global security tools and capabilities available. In international terms, the integration of Kosovo in future political institutions and regional and global security, such as the European Union, the United Nations and the Organization of the North Atlantic Treaty, the main objective of the state is directly related to the country's progress. Kosovo is committed to be in line with good neighborly relations and to develop relationships with regional and international partners, based on mutual understanding and cooperation. Violent extremism and terrorism show that not necessarily serious threats emanating from state actors. Moreover, recent events such as the global financial crisis and the spread of cybercrime and electronic interference, demonstrate that innovative approaches are necessary to protect national security. (KSS 2010:6)

\section{Relations with International Security Organizations and Approaches to the International Order}

All documents advocate the preservation of international order, but special emphasis is given to the equality of states (Croatia, Macedonia, Serbia), and to adopting a multilateral approach in resolving security issues (Montenegro). Similarly important is the common view that violent disputes have to be prevented. Although the security documents depict the UN, the OSCE, NATO, and the EU as the most important actors of international security for the Western Balkans region, and describe the basic characteristic features and changes of the post-bipolar world order, they do not elaborate on the ongoing changes in the aforementioned security institutions. Furthermore, they do not identify their specific attitude towards them, or specify the desired evolution of the international order in comparison to the way these issues are dealt 
with in the security strategies of the Central European countries or the European Security Strategy. None of the documents mention a key notion of the EU's security concept, namely "effective multilateralism".

The EU is generally perceived as a security organisation closer to the Organization for Security and Cooperation (OSCE) in Europe than to NATO, and the European Security and Defence Policy (ESDP) is dealt with only marginally. As to the NATO-ESDP link, most documents limit themselves to stating the complementary nature of the EU's efforts in the defence field, thus avoiding discussion of problems related to NATO-EU relations.

The Serbian and Croatian strategic documents are exceptions in this general picture, since they elaborate more specifically on international security institutions and their vision of the desired international order. Although all their documents mention international law, the Serbian documents place particular emphasis on this issue, and refer in detail to basic principles, standards and documents of international law. Further, according to the Serbian documents, the respective roles of the UN, OSCE and EU organizations should be reinforced. The Serbian documents even recommend "revitalization" of the UN, indicating Serbia's acknowledgement of the importance of that institution. The relevant Croatian documents describe the world order as unipolar, but foresee the possibility that "future international relations develop from a unipolar to (a) multipolar world." When deciding on participation in international peacekeeping missions, three aspects are taken into consideration, including the "valid ground for the mandate in terms of international law." (Gyarmati I. and Stančić D.2007:38)

KSS 2010 states that Kosovo is engaged and continues to develop successful cooperation with international presences in Kosovo as NATO / KFOR, International Civilian Office / European Union Special Representative (ICO / EUSR) and the mission of the European Union Rule of Law Mission (EULEX). In international terms, the integration of Kosovo in future political institutions and regional and global security, such as the European Union, the United Nations and the Organization of the North Atlantic Treaty, are the main objective of the state is directly related to the country's progress. (KSS: 4)

\section{Concluding Remarks}

The paper studies the emergence of the strategic culture of the Western Balkans through the study of National Security Strategies of the states of this region. It argues that Strategic Culture can be judged in terms of the depiction of Interests and Values stated by these states in these overarching security documents as well as in terms of the approaches declared regarding Regional Security Cooperation and Relations with International Security Organizations and Approaches to the International Order.

Ideas on security issues are developed by historic events which enrich the experiences of a particular collective which deals with issues of security while these ideas are also shaped by the development of National Security Documents. A comprehensive study of the security issues in the Western Balkans may utilize Strategic Culture as an analytical tool through the study of national Security Strategies in the plethora of variables in the regional security studies.

\section{References}

National Security Strategy of Albania,2004

Security Policy of Bosnia Herzegovina, 2006.

National Security Strategy of Croatia, 2002.

National Security and Defence Concept of Macedonia 2003.

Strategy of National Security of Montenegro, 2006.

National Security Strategy of Serbia (Drafts)2007.

Security Strategy of Kosovo was adopted in 2010.

Giegerich, B. (2006) European Security Strategy and Strategic Culture. National Responses

to the EU's Security and Defence Policy, Baden-Baden : Nomos Verlagsgesellschaft.

Gyarmati, I. and Staneie, D, (Editors) Study on the Assessment of Regional Security Threats and Challenges in the Western Balkans Geneva Centre for the Democratic Control of Armed Forces (DCAF), 2007,

Filip Ejdus, Towards the Western Balkans Security Community, published in "Western Balkans Observator", Faculty of Political Science, Belgrade, December, 2011. First published at Europe's World Community, at http://bit.ly/vtJnDe

Hadzic M, Timotic M and Petrovic P, Security Policies in Western Balkans: Center for Military Relations Belgrade.

Law D,(2007), Best practices in the field of national security, (eds) Toci F.On the development of the national security strategy, Institute for Democracy and Mediation, Tirana, Albania. 